\title{
An Analysis of the Relationship between Lifestyle and Social Organization of Work (With an Accentuation on Body Management): A Case Study on Workers of Gol Gohar Sirjan Mining and Industrial Companies
}

\author{
Muhammad Javad Shahba
}

PHD Student of Cultural Sociology at Islamic Azad University of Dahaqan Branch Electronic Post: raha3561@yahoo.com

Dr. Ismail Jahan Bakhsh

Assistant Professor of Cultural Sociology at Islamic Azad University of Dahaqan Branch

Dr. Mansour Haqiqatian

Assistant Professor of Cultural Sociology at Islamic Azad University of Dahaqan Branch

Doi:10.5901/mjss.2016.v7n4s1p266

\section{Abstract}

\begin{abstract}
Work at mining and industrial companies does not only require physical strength, but it involves many different cultural and social aspects as well. The organization of work is a concept that has been widely accentuated on different fields such as: management, social sciences and of course sociology. The organization of work can be divided into two formal and informal dimensions. Body and appearance management is a very important social and cultural structure that is derived from our environment and especially our work environment. The purpose of this study is to analyze the relationship between the work organization and body-appearance management of workers of Gol Gohar Sirjan Mining and Industrial Companies. The data of this study was gathered from a sample consisting of 384 workers of Gol Gohar Sirjaan Companies, elicited by means of random sampling methods. The data analysis of our study was carried out by multiple regressions and Pearson's correlation technique. The results of our multiple regression showed that there is a strong relationship between the variable of informal work organization and the body and appearance management of the workers.
\end{abstract}

Keywords: Mine, social work organization, formal relationships, informal relationships, body management

\section{Introduction}

Since the beginning of time Human Beings had to work in order to meet their basis needs. Working is an inseparable part of everybody's routine. With the evolution of human beings and the progression of technology, the type of works or jobs has evolved as well. There was a time when humans engaged in hunting for food and animals in order to survive, then they discovered farming and then with the industrial revolution most people took a job in industrial companies. Modern technologies give humans such power that they are now able to intervene in the works of nature, use the resources hidden deep under the land in order to meet their newly emerged needs. Working at mining and industrial environment has its own requirements and characteristics. In those environments people change their behavior in order to adapt with changes of technology, mine, industry etc. Sometimes people have to take on in physically demanding jobs in order to make their ends meet.

In the past, production units had lots of limitations, meaning workers were autonomous and their daily work was a part of their daily life. However, the industrial revolution changed these concepts completely and separated people's life and work for good. In other words what was happening outside of work was the result of what workers had created in the social organization of work. Work places and their environment created a certain social organizations in accordance to workers' skills and their knowledge of technology.

Modern work itself can be considered as a social phenomenon, because people become members of their work groups or group of workers. Bigger working environments might have bigger and multiple work groups, For example the production line of a factory (huge factories with many workers) may consist of many work groups. It is worth mentioning that lots of human relationships regulations are imposed in order to create a friendly environment for the workers and to 
improve their social environment as much as possible (Tavakoli, 2002 p 18-19)

Poulani (1980) points out that:" The economic system of work is differentiated by its habits and relationships, then these relationships influence the society in way y that the economic attitudes of work along with its logical aspect effects the society." (Weiss Vadeh, 2005).

Work in itself is a social phenomenon in terms of its linguistic aspects. In other words "work" alone is not a tangible concept but it is rather a social activity, and this builds the social organization of work. The difference between what is accepted as work or what is not accepted as it, is hugely related to the social texture in which a work is available. It is worth mentioning that this texture changes with the passage of time and the evolution of places (grinet, 2003).

So, what is the social organization of industrial work? It can be defined as an organization in which people define their type of work within its production system. Work is not just an activity in which we engage just to meet our material needs; it also has its own social traits and characteristics that define it. Having a permanent job is not only shapes people's character and elicits certain amount of energy from them but it also gives them a certain identityl. The production system of Fordism system of work doesn't trust workers and gives them little room for creativity, this system robs people from their identity within a 20 to 30 time period (Giddens, 2002).

As Herbert Hughes points out:" Modem people build their sense of identity through their job and profession." Study shows that workers at factories and offices are willing to build certain cliques and groups within their organization. Those groups might influence people's self esteem, productivity and their attitude towards racial discrimination (Swedenberg, 2012 p: 124).

As mentioned earlier the social organization of workits two formal and informal aspects has a huge influence on workers behaviors and attitudes.

Formal structures were designed in order to change people's behavior toward a certain goal, thus these structures are hugely different from their informal counterparts. Formal structures consist of certain norms and behavioral models that work independently from the individual factors. On the other hand informal structures are based on workers' certain personality traits and relationships. Berger and Dickson believe that:" As much as informal structures are got to do with workers' emotions and certain feelings, the formal ones are based on the cost and efficiency logic (which managers have designed)," (Scott and Davis , 2010 , p 124-122).

Formal structures make sense of workers' positions and relationships and bys standardizing their behavior, tries to predict their future actions. Formal structures are not dependent upon certain people or their talents, because it has the required mechanism to simplify the jobs and consequently eliminates the need for any certain talent. However, organizational tactics alone are not enough to determine workers' social attitudes and behaviors. As a matter of fact workers' values, wants, needs, emotions etc. within a formal structure shape the informal structure of that organization. Without first analyzing the informal networks of an organization understanding the nature of its formal structures would be impossible, even though both (formal and informal organizations) greatly influence workers' behaviors. Unlike formal structures that are made intentionally the informal instructors are unconsciously created in accordance to workers' work relations (Qoli Pour, 2001, p; 28-27).

In this study we hypothesized that work in the open and modern mine of Gol Gohar has created certain social and cultural needs . In other words a meaningful relationship between the social organization of work (formal and informal) and the varied group of workers and their lifestyle and body management is obvious.

\section{Literature Review}

1. In their study "Body as a media for identity", Azad Armaki and Chavoshian (2002) analyze the identity forming ability of structures. Their study follows a cluster multi- level method and its statistical society consists of 822 older than 18 years old residents of Tehran, Their results found a meaningful relationship between the level of body management and variables such as: sex, age cultural capital and the level of education. This study didn't find any link between levels of body management and people's jobs or line of work.

2. In his study "An analysis of the link between body management related activities and social identity" Ahmadi Tayeb (2007) carried out a multi level cluster study of 400 older than 18 years old residents of Rasht. He could find any link between economic capital and body management but found a meaningful relationship between cultural capital and body management. He also found that gender differentiates people's way of body management.

3. In his study "An analysis of the influence of social atmosphere of an organization on the working life quality of industrial workers" (Case study carried out in Eastern Azerbaijan province) Ziaie Bigdeli (2009) analyzes this issue thoroughly. The concept of working life quality refers to a process within which all the members of an 
organization build an open and consistent relationship with each other. The statistical society of this study was 300 workers of Tabriz factories and the rate of their working life quality was determined $49 \%$, which is an average rate. This study found a strong link between reduction of work pressure, work relationships, professional commitment and the working, life quality of workers. Finally, this study proved that the productivity of these factories is $45 \%$ dependent upon on the workers' working life quality.

4. Jung and Lee (2006) have also conducted a study on the culture of body image, self esteem and dieting among Korean and American women. The statistical sample of their study was consisted of 201 women from the central university of Seoul in Korea and also 205 women from Mead University in the United States. The results of their study showed: a great link between body image and self esteem and an incompatible relationship between body image and dieting, Jung and Lee concluded that Korean women were less satisfied with their body image than their American counterparts.

5. In their study "Body management and its relationship with social acceptance of the body" Fathi and Ekhlasi (2008) found that women pay too much attention to different aspects of (e.g. aesthetically, personal care) body management. They've found a meaningful relationship between variables such as media consumption, social acceptance, social and economic place and body management. They have also found a meaningful and paradoxical relationship between religious practices and body management,

6. In a case study on young people of Babolsar city titled "Sociological analysis of body management and personal identity" Shahram Parastesh (2009) analyzed young people of 15-25 years of age on this issue, the statistical sample was consisted of 380 people. . The results showed that there is a strong link between appearance management and identity. In other words if people have had more options they would pay much more attention to identity.

7. In his study "White Collar Proletariats" Malcolm Carry has analyzed a group of social work managers and their hatred toward their work. He concluded that skill elimination, demanding work schedule and strict rules are factors that might make people hate their jobs.

8. In his book "copper worker international business and domestic politics in cold war, "Vergara (2008), analyzes the history of copper mine workers in Chile and pays close attention to foreign ownership of copper industries , military dictatorship and the nationalization of copper industry in Chile.

9. In a paper titled "company towns and peripheral cities in the Chilean copper industry:" Vergara (2003) again looks at the gradual evolution of company towns during 1917-1940. He claims that the industrialized structure of these towns has causes social and cultural paradox in their peripheral cities.

10. In another paper called "Labor formalization and declining inequality in Argentina and Brazil in 2000 s" Maurizio Roxana,(2014) points out the flexible role of market in employment and reduction of unequal wages, $\mathrm{He}$ accentuates the role of education in this study.

11. In his study "Bonded labor in India: its Incidence and Pattern "Srivastava, Ravi S (2005). Analyzes the issue of bonded labor between 1949- 1976. This study treats the historical documents on this issue as a tool for recognizing the changes in the bonded labor pattern. This study found that thanks to efforts of a judge and judicial activist bonded labor has improved in India since 1997.

\section{Theoretical Framework}

The sociology of the organization presents a wide variety of views and ideas about the social organization of work. Classic sociologists such as Dorkim accentuate the organic and mechanic society and the importance of dividing work responsibilities. Weber on the other hand, discuses the concepts of bureaucracy and rationality, He condemns hierarchy systems in organizations and describes it as an iron cage which is in the way of its progression.

Taylor presents yet another different view on organizations. His Theories known as Taylorism gives a mechanical model of the organization. He compares human beings with soulless machines and accentuates the efficiency of treating humans as such in ordere to reach the planned goals of organization (Parhizgaar, 1985).

Taylorism states that workers and the work are the main units of decomposition and analysis of the work. His mechanical point of view is so pervasive that it can be tracked down even in his attitude toward employers. He treats employers the same way he treats the workers, in other words he believes that employers are efficiently oiled cars that can be replaced anytime if necessary (Desler , 2001).

In contrast to the above point of views there are human relations approaches. These approaches study the social organization of informal work and the informal relationships of workers.

Human relations theory states that the attitude and behavior of a person is based on group values and criteria and 
this is something that managers can use to their advantage. Thus; if managers want to organize and manage the informal groups within their organizations they need a pattern different from the pattern of scientific management. An informal group usually consists of workers with social drivers instead of economic drivers. Groups like these fill the social needs of organizations and their values are different from management values (Tavassoli, 2002).

The teaching of human relations concept added different variables such as informal relationships to the organizational theories, and it was followed by Tavistock's social and technical discussions which completed the continuum of human relations.

Back then work groups were not considered to be social or technical organizations, and the works of Tavistock institution, like Hawthorne studies was based on the hypotheses of the balance model. However, in the new method technical changes are treated as changes that break down the former technical mechanical balance and the response of miners is considered to be a reaction to it. The current situation of coal mines used to be analyzed as social and cognitional forces which derive their balance from the technical and social balances (Bouriel \& Morgan , 2007 , p ; 203-204).

We accentuate the theories of Giddens in concern with the other variable of our study which is life style and body management.

One of the most inseparable parts of lifestyle discussions is the subject of "body", something that Giddens describes as a "reflective project". Our bodies are the best and most obvious representatives of our lifestyle. Thus identifying the related factors in designing this project can be of great use.

Giddens doesn't treat body as just a tool for taking a certain action or showing a certain reaction, He considers body as a natural machine whose owner should take very good care of, Human's body is a symbol of dignity and is a threshold for many pains and pleasures. New born babies of human beings are not able to take proper care of themselves for the first few years of their lives. Thus parents of a child should make sure that his or her needs are properly met. Their methods of providing food or shelter for their baby can be treated as something like a "diet". In other words when an adult follows a certain diet its success or failure is dependent upon a specific culture. This also applies to sexual behavior. Our way of clothing also follows a certain "diet". Clothes are simple tools for presenting an overall identity of people to the outside world. Giddens believes that "food diets are fundamentally important for the identity of an individual, because habitual behaviors are related to some obvious aspects of our bodies." The way people eat or their table manners are an exhibition of their cultural habits that also affect the appearance of their bodies, and probably give us clues about their personal backgrounds and the image that they have created of themselves (Giddens, 1998), Giddens goes as far as calling the body a part of an action system, in other words he believes that reflections extends to our bodies as well. He thinks that controlling our bodily processes is actually a reflective reaction that a doer should show toward his or her behavior. Being aware of certain changes of our bodies is of upmost importance, this and checking the state of the main organs is of up most importance. This awareness also includes being aware of the positive effects of exercising along with following healthy diets. As Rainwater points out" People always talk about their intention to diet, they are not aware that we are all following a specific diet. What we eat or drink is our diet or regimen with the difference that this kind of dieting is decided upon on a daily basis," (Giddens, 1998).

Therefore, it Is obvious that through body management (taking care of apperace, dieting, exercising etc) people try to distinguish themselves from the others or find a certain identity for themselves. The process of body management is something that a person can change its patterns according to different social situations or environments.

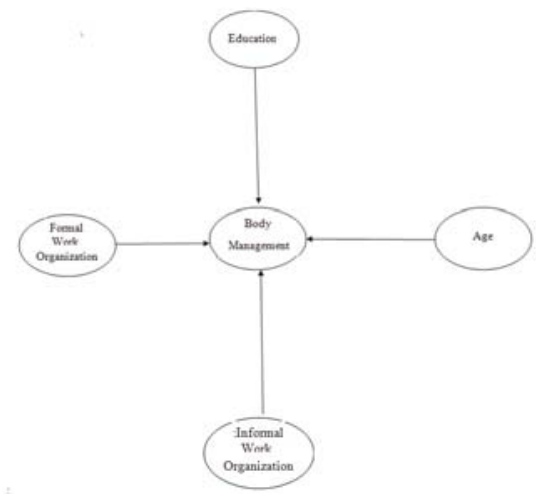

Figure 1: The Theoratical Model of study 
Thus, the hypotheses of our study are as follows:

1. There is a certain relationship between the formal social organization of work and the body management of Gol Gohar workers.

2. There is a certain relationship between the informal social organization of work and the body management of Gol Gohar workers

3. There is a relationship between their level of education and their body management.

4. There is a relationship between their age and their body management.

\section{Method of Study}

The statistical society of every study is a set of people or units that share at least one common industry (Sarmad et al., 2001), The statistical society of this study consists of Gohar Ravesh and Jihad Nasr Companies which are sub branch companies of Gol Gohar Sirjan head company which has 2000 employees. However, we have taken our sample by studying 384 employees and our method was based on random sampling. The analysis unit of this study is an individual and its level is minor, our study was a field study and its tool was a questionnaire. The validity of our data was assessed by artificial validation and its reliability was measured by means of Cronbach's Alpha. It is worth mentioning that we omitted the factors that were reducing the scale of Alpha. Table 2 summarizes the related Alpha of for each varaiable.

Table 1: Reliability Coefficients for Study's Variables

\begin{tabular}{cc}
\hline Rate of Alpha & Variable \\
\hline .71 & Body Management \\
.68 & The Formal Social Organization of work \\
.70 & The Informal Social Organization of work \\
\hline
\end{tabular}

It is worth mentioning that the dependent variable (Body Management) is represented with the factors below:

Weight control, medical manipulations, rate of attention to cosmetic and hygienic care, choice of clothing, hair style use of accessories etc..

Moreover, the independent variable of formal social organization of work is represented with factors such as: regulatory rules of organization, contracts, hierarchy, and the methods of retirement, methods of promotions, bureaucracy, and methods of management.

Additionally, the other independent variable of informal social organization of work is also represented with factors such as: social relations, social validation, social trust, social contribution and conflicts between workers.

\section{Study Findings}

In this section we discuss the findings of our study about the background variables and then we analyze the relationships between each couple of them. To do so we have used multiple regressions, sticking coefficient and variance analysis techniques.

\subsection{Demographical Variables}

We have summarized the age distribution of study's participants in table 2. As you can see people between the ages of 26-30 were the majority of our responders (42.2\%) and people older than 40 have the lowest rate of responding. The average age of our statistical society was estimated 30 .

Table 2: The Statistical Society Based on Age

\begin{tabular}{ccc}
\hline Percent & Rate & Age \\
\hline 23.2 & 89 & $\mathbf{2 5 - 2 0}$ \\
42.2 & 162 & $\mathbf{2 6 - 3 0}$ \\
22.1 & 85 & $\mathbf{3 1 - 3 5}$ \\
10 & 37 & $\mathbf{3 6 - 4 0}$ \\
3 & 11 & Older Than 41 \\
100 & 384 & Total \\
\hline
\end{tabular}


Table 3 shows the statistical society of our study based on their level of education. The majority of our responders (159 people- $41.4 \%$ ) had associate and bachelors degree and the minority of our responders (10 people $-2.6 \%$ ) had a masters degree.

Table 3: The Statistical Society Based on Level of Education

\begin{tabular}{ccc}
\hline Percent & Rate & Level of Education \\
\hline 17.7 & 68 & Middle School Education \\
38.3 & 147 & High School Diploma \\
41.4 & 159 & Associate and Bachelor Degree \\
2.6 & 10 & Masters Degree \\
100 & 384 & Total \\
\hline
\end{tabular}

Table 4 shows the statistical society of our study based on their job positions. As you can see the majority of our responders were amongst laborers (378 people - 98.5\%) and the minority of our responders was amongst senior managers (1 person- $0.3 \%)$.

Table 4: The Statistical Society Based on Job Positions

\begin{tabular}{ccc}
\hline Percent & Rate & Job Positions \\
\hline 98.5 & 378 & Laborer \\
1.3 & 5 & Middle Manager \\
0.3 & 1 & Senior Manager \\
100 & 384 & Total \\
\hline
\end{tabular}

The independent variable of this study is the social organization of work (formal and informal) and its rate can be seen in tables 5 and 6 . As you can see the majority of our responders (56.6) consider the rate of formality at gol gohar Iron Ore Company to be average and the minority of our responders $(0.7 \%)$ described it as very high.

Table 5: The Rate of Formal Social organization of Work

\begin{tabular}{ccc}
\hline Percent & Rate & Level of Formality \\
\hline 1.5 & 6 & Very Low \\
30 & 116 & Low \\
56 & 215 & Average \\
11.5 & 44 & High \\
0.7 & 3 & Very High \\
100 & 384 & Total \\
\hline
\end{tabular}

The other independent variable of this study is the informal organization of work. As you can see in table 6 the majority of our responders (40\%) described this variable as low and $1 \%$ described it as very high.

Table 6: The Rate of Informal Social organization of Work

\begin{tabular}{ccc}
\hline Percent & Rate & Level of Formality \\
\hline 34.00 & 131 & Very Low \\
40 & 151 & Low \\
17 & 65 & Average \\
8.0 & 32 & High \\
1 & 5 & Very High \\
100 & 384 & Total \\
\hline
\end{tabular}

The dependent variable of this study was the variable of body management and its rate can be seen in table 7 . The targeted workers considered things like (Hair style 84.6, clean shave $86 \%$, use of cotton pants $90 \%$, use of jean pants $68 \%$, hair gel use $84 \%$ and designer clothes $55 \%$ ) to be important . this shows the depth of superficiality of today's society in which "body" is a key element of for building people's character and personality. 
Table 7: The Degree of Body Management amongst the Statistical Society

\begin{tabular}{cccccc}
\hline Very Low & Low & Average & High & Very High & Factors of Body Management \\
\hline 32 & 17.7 & 15.6 & 24.2 & 10.4 & Use of Deodorants \\
10.4 & 2.1 & 32.3 & 48.2 & 7 & Use of Designer Clothes \\
43.5 & 22.9 & 12.8 & 17.4 & 3.4 & Use of Accessories \\
3.9 & 3.1 & 8.3 & 24.2 & 60.4 & Hair Style \\
5.5 & 1.3 & 8.3 & 28.9 & 56 & Facial shave \\
32.2 & 11.7 & 10.7 & 25 & 20.3 & Use of Cologne and Perfume \\
6.3 & 0.8 & 8.3 & 27.9 & 56.9 & Use of Hair Gel \\
2.6 & 3.1 & 10.2 & 31.5 & 52.6 & Use of Hair Care Products \\
22.7 & 10.2 & 21.9 & 30.7 & 14.6 & Body Building \\
3.6 & 0.8 & 27.1 & 22.9 & 45.9 & Using Jean wear \\
2.1 & 1.6 & 5.7 & 20.6 & 70.1 & Use of Cotton Wear \\
\hline
\end{tabular}

\subsection{The Correlations between Independent and Dependent Variables}

Table 8 summarizes the relationship between 4 independent or dependent variables'. As you can see the only variable with the meaningful relationship was the informal organization of work, This relationship has the reliability of 95\%.

Table 8: The correlation between independent and depended variables (social organization of work and body management)

\begin{tabular}{ccc}
\hline Level of Meaningfulness & Rate of correlation & Independent Variables \\
\hline 0.9 & .7 & Formal Organization of Work \\
0.00 & .68 & Informal Organization of Work \\
0.13 & .01 & Level of Education \\
0.4 & .36 & Age \\
\hline
\end{tabular}

As you can see the coefficients for both variables has been calculated and the results shows a meaningful relationship between the informal organization of work and body management.

\subsection{Multiple Regression Analysis}

Table 9: Elements of body independent variables within the equation for determining body management

\begin{tabular}{ccccccccc}
\hline $\mathrm{R}_{\mathrm{Ad}}{ }^{2}$ & $\mathbf{R}^{2}$ & $\mathbf{R}$ & $\mathrm{T}$ value & Meaningfulness & Beta & $\mathrm{B}$ & Independent variables & Level \\
\hline 0.47 & 0.46 & 0.68 & 9.6 & 0.00 & 0.68 & 0.69 & The formal social organization of work & 1 \\
& & & Constant $=8 / 1$ & $\mathrm{~F}=33$ & $\mathrm{sig}=00.0$ & \\
\hline
\end{tabular}

In this study we have used the stepwise multiple regression technique and the variable of informal social organization of work turned out to be the intervening variable. In this model the correlation coefficient was calucated $68 ? \%$ and its coefcient was 47\%. . Thus the informal social organization is related to body management. As you can see on table 9 the $\mathrm{F}$ rate in $99 \%$ level proves that this correlation is not random. Therefore the multiple regression equation of this study can be written as:

$\mathrm{Y}=\mathrm{a}+\mathrm{bx} \mathrm{x}_{1}+\mathrm{b} \mathrm{x}_{2+\ldots . . .} \mathrm{bx_{n }}$

Body management: $8.1+0.68 \mathrm{X}$

Thus, only the beta amounts can determine the role of each variable. Because these amounts are standard they can provide the chance of relative comparison and of each variable. However, the $B$ rate shows the amount of informal organizational work to be $69.0 \%$. But since the beta amount should show the rate of /68 so each one unit of change in the pattern of informal work organization changes $68 \%$ of the dependent variable (body management).

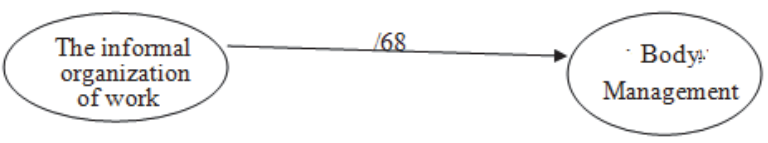




\section{Discussion and Conclusions}

The modern social organization of work is a social phenomenon. People become members of a small group then they become members of factories or mining and industrial working groups. For example the electricity section of our targeted mining and industrial company gives a sense of group cooperatiobn to workers. It is worth mentioning that most of the regulators of laborers relations contsnalty try to manipulate these relations and consequently change the social envitonemtn of the workplace. This study analyzed the relationship between the work organization and body-appearance management of workers of Gol Gohar Sirjan Mining and Industrial Companies. Our results showed a strong link between informal social organization of work and body management. In other words the more informal a work place the more workers would pay attention to body managemner. On the other hand regulatory rules, hierarchy systems, ,methods of management, contracts, working hours method of promotions etc does not have any affect on body management of workers. Our results showed that our targeted statsical society wanted to look attractive and young, thus in that sence our study matches the result of Azad Armaki and Chavoshian (2003). This paper also confirms Giddens's theory of modern human's identity and his or her working relationship. Thus, we believe that the results of social factors should be taken into considerations in order to study cultural behaviors of Gol Gohar workers.

\section{References}

Azad Armaki, Taqi, Chavoshian, Hassan, 2003. Body, as a media for identity, the sociology association magazine,

Ahmadu, Tayyeb 2007, body management and identity, masters degree thesis, University of social sciences of Gilan

Scott w. Richard, Davis Gerald F. 2010, organizations and organizing, Translator : sayyed Reza Seyd Javadin et al, Morvarid Publications

Bouril Gibson, Morgan Garth, 2007, Tranlator Nourouzi, Major theories of sociology and decomposition and analysis of organization, Samt Publications

Tavassoli, Qolam abbas, 2002, sociology of work and profession, Tehran, Samt Publications

Paratsesh Shahram et al. Case study on Babolsar City : an analysis of bodymangement and its effects on individual identity Social Sciences Magazine,Ferdowsi Uiversity os Mashhad

Swedberg, Richard, 2011, Advantage Seeking and Social Structure, Translator Ali Asqar Saeidi, Louh E Fekr Publications

Ziaiei Bigdeli, Muhammad Taqi, 2009, Analyzing the effects social atmosphere on working life quality, Efficient sociology Magazine, Spring of 2009, no, 1

Fatehi, Abolqasem \& Ekhlassi Ibrahim 1999, The Link between body management and body image, Research Magazine of Isfahan University

Qoli Pour, Aryan, Socilogy of organizations, sociology's approach towards organizastons and management, Tehran, Samt Publications

Grinet Keith, 2002, the background of work sociology, translator Parviz Salehi, Tehrna, Mazyar Publications

Giddens Anthony, 2002, Sociology, Tranlsator: Manouchehr Sabouri, Ney Publications

Giddens Anthony, 1999, Modernity and Personality, : The coiety and Identity in the New age, Translator:Naser Movafaghyan, Tehran, Ney Publications, Second Edition

Weiss Wade Gonther, 2002, Sociology for the Economy, translator Hadi Samadi, Samt Publications

Carey Malcolm,(2007) white-collar proletaria? Available in http://jsw.sagepub.com

Hillier, J.\&Rooksby,E (2002) habits : a sense of place, Aldershot: Ashgate.

Jung, Jaehee \& Lee, seung-Hee (2006) cross- cultural comparisons of Appearance self Schema, body image, self- esteem, and dieting behavior between Korean and US

Maurizio Roxana,(2014) Labour formalization and declining inequality in Argenyina and Brazil in 2000s, Publication of the International labour office, ISSNWeb/pdf:2306-0875(online version)

Srivastava, Ravi S,(2005) bonded labour in india: its incidence and pattern. Publication of the International labour office. Available in www.ilo.org

Vergara, Angela(2003) company towns and peripheral citie in the Chilean copper indudtry: potrerillos and pueblo Hundido, 1917-1940s, urban History, Cambridge university press. A

Vergara, Angela(2008), copper worker international business and domestic politics in cold war, chile press university park, pensylvania 